\title{
ANALISIS RISIKO MESIN BAGGING SCALE DENGAN METODE FUZZY FAILURE MODE AND AFFACT ANALYSIS (FUZZY-FMEA) DI AREA PENGANTONGAN PUPUK UREA PT. PUPUK SRIWIDJAJA
}

\author{
Agus Mansur ${ }^{(1)}$, Rastiti Ratnasari ${ }^{(2)}$ \\ Teknik Industri, Fakultas Teknologi Industri, Universitas Islam Indonesia \\ Email: ${ }^{(1)}$ agusmansur.am@gmail.com, ${ }^{(2)}$ rastitiratna@gmail.com.
}

\begin{abstract}
Production process continuity is highly influenced by machine performance. Meanwhile, in order to maintain production process running smoothly, risk management activities such as failure process analysis is utilized to anticipate any damage which might occur in the production facilities. This research was conducted in PT. PUPUK SRIWIDJAJA, especially at urea fertilizer packaging division on October 2015. Moreover, due to bad condition of old engine, damage occurs in the fertilizer packaging machine every week. The research aims to determine the priority of failure which gives the greatest risk toward fertilizer packaging process. Fuzzy FMEA is used in this research. The result shows that, the damage because of air cylinder leakage gives the greatest risk in failure of fertilizer packaging.
\end{abstract}

Keywords: risk analysis, process failure, Fuzzy FMEA

\section{PENDAHULUAN}

Kelancaran suatu proses produksi sangat dipengaruhi oleh kinerja suatu mesin. Agar proses produksi berjalan lancar maka diperlukan sebuah proses manajemen risiko yang baik dalam menyeleseikan suatu permasalahan berupa kerusakan peralatan produksi/mesin di perusahaan tersebut. Apabila dalam sebuah industri terdapat beberapa macam kerusakan, maka pihak perusahaan harus mampu membuat perencanaan perbaikan yang baik. Penggunanan mesin yang terus menerus serta usia mesin yang sudah tua menyebabkan mesin menjadi aus dan terdapat banyak trouble yang bermunculan. Besarnya biaya investasi dalam membeli suatu mesin membuat perusahaan berupaya keras melakuakan perawatan terhadap mesin agar mesin bisa tetep beroprasi dengan lancar dan menghasilkan produk yang sesuai dan meminimalkan produk cacat yang disebabkan banyaknya trouble dari mesin tersebut
PT. PUPUK SRIWIDJAJA merupakan salah satu perusahaan industri yang memproduksi pupuk urea sebagai produk utamanya. Salah satu mesin yang digunakan PT. PUPUK SRIWIDJAJA yaitu mesin Bagging Scale yang merupakan mesin pengantongan pupuk pupuk urea dalam bentuk karung yang beroprasi selama 24 jam sesuai dengan shift pekerjanya. Mesin baru berhenti oprasi ketika tiap shiftnya pekerja sudah memenuhi target dengan mengantongi 200 ton pupuk urea. Tidak kurang dari 2 jam mesin sudah harus beroprasi kembali. PT. PUPUK SRIWIDJAJA memiliki target produksi dimana harus memproduksi 4000 ton pupuk urea setiap harinya dalam bentuk bag. Oleh karena itu, perusahaan harus bisa meminimalkan risiko yang akan timbul dari mesin tersebut agar mesin bisa bisa terus beroprasi dan memenuhi tagrget pengantongan. .

Manajemen risiko adalah proses pengukuran atau penilaian risiko serta pengembangan strategi pengelolaannya. Manajemen risiko bertujuan untuk mengelola risiko sehingga organisasi bisa bertahan, dan 
juga bisa mengoptimalkan risiko ketidak pastian (Roger. S. Pressman). Manajemen risiko pada dasarnya dilakukan melalui proses-proses berikut ini : Identifikasi risiko, Evaluasi, dan pengukuran risiko, Identifikasi risiko secara akurat dan komplit sangatlah vital dalam manajemen risiko (Roger S. Pressman). Salah satu aspek penting dalam identifikasi risiko adalah mendaftar risiko yang mungkin terjadi sebanyak mungkin. Tujuan dari evaluasi risiko adalah untuk mengetahui karakteristik risiko yang lebih baik tentang risiko yang terjadi dapat memudahkan kita untuk mengelola risiko tersebut (Mallman, 1996), Proses selanjutnya yaitu mengelola risiko. Jika organisasi gagal mengelola risiko, maka konsekuensi yang diterima bisa cukup serius, misalnya kerugian yang besar bahkan bisa bangkrut

Dalam penelitian ini, FMEA digunakan sebagai salah satu alat dalam menganalisis sebuah risiko pada suatu mesin pengantongan pupuk dengan dengan mempertimbangkan prioritas atau nilai Risk Priority Number (RPN). Selain itu juga untuk menilai factorfaktor risiko dan disempurnakan dengan menggunakan metode fuzzy. Dalam FMEA konvensional, penilaian factor-faktor failure mode yaitu faktor severity (S), faktor occurence $(\mathrm{O})$ dan faktor detection (D) yang diterap kan dalam natural language akan menghasilkan informasi yang tidak tepat (ambigue) dan bersifat samar (vague) (Yeh et all., 2007). Penggunaan teori fuzzy memberi fleksibilitas untuk menampung ketidakpastian akibat samarnya informasi yang dimiliki maupun unsur preferensi yang subjektif yang digunakan dalam penilaian terhadap mode kegagalan yang terjadi. Banyak pendapat para ahli bahwa faktorfaktor S, O dan D tidak mudah untuk dievaluasi secara tepat. Upaya yang signifikan telah dibuat untuk mengevaluasi risiko dengan cara linguistik (Wang et all., 2009).

Dari permasalahan diatas, akan dibuat sebuah analisis risiko dari kerusakan yang timbul pada mesin Bagging Scale untuk dijadikan fokus usulan perbaikan dalam meminimalkan risiko yang terjadi terhadap proses pengantongan pupuk pada mesin tersebut. Metode yang digunakan dalam penelitian adalah Fuzzy FMEA (FuzzyFailure Mode Effact Analysisi).

\section{METODE}

Dalam penelitina ini akan dilakukan analisis risiko mesin Bagging Scale pada Departemen pengantongan pupuk urea di PT. PUPUK SRWIDIDJAJA dengan tiga Langkah yaitu : mengidentifikasi risiko dari jenis kerusakan yang sering terjadi, melakukan penilaian faktor risiko dan menentukan prioritas perbaikan dari mesin tersebut.

Penelitian ini dilakukan dengan 2 cara yaitu dengan obesrvasi langsung dan wawancara, dan didapatkan data primer dan data sekunder. Data primer didapatkan langsung dari expert bagian maintenance yang sudah lebih dari 10 tahun menangani mesin tersebut. Wawancara tersebut dilakuakan untuk mendapatkan penilaian dari hasil faktor-faktor risiko. Data sekunder didapatkan dari data laporan harian selama satu tahun pada bagian maintenace didepartemen pengantongan untuk mendapatkan jenis kerusakan apa saja yang sering terjadi pada mesin Bagging Scale.

Berdasarkan uraian masalah sebelumnya, penelitian ini akan mengidentifikasi risiko dengan cara menentukan impact dan probability suatu risiko. Kemudian dilanjutkan dengan penetuan prioritas berbaikan dengan mempertimbangkan faktor-faktor risiko dengan menggunakan metode Fuzzy FMEA.

\subsection{Identifikasi Risiko}

Langkah awal yang dilakuakan dalam menganalisis suatu risiko sebuah mesin yaitu mengidentifikasi risiko yang timbul dari kerusakan mesin yang sering terjadi dari data laporan harian selama 1 tahun. Dalam analisis risiko,setelah melakukan identifikasi risiko kemudian mengolah data yang 
diperoleh untuk mendapatkan profil risiko dan melakukan penilaian terhadap risiko tersebut. Penilaian risiko pada dasarnya mengacu pada dua faktor, yaitu: kuantitas risiko dan kualitas risiko. Kuantitas risiko terkait dengan berapa banyak nilai, atau dampak, yang rentan terhadap risiko.
Sedangkan kualitas risiko terkait dengan kemungkinan suatu risiko muncul. Pada penelitian ini dimensi kemungkinan risiko muncul dibagi ke dalam lima kategori, yaitu almost never, unlikely, possible, likely, dan almost certain seperti terlihat pada Tabel 1 .

Tabel 1. Dimensi Kemungkinan Terjadi Risiko (Likelihood)

\begin{tabular}{lll}
\hline \multicolumn{3}{c}{ Kemungkinan (Likelihood) } \\
\hline Level & \multicolumn{1}{c}{ Deskripsi } \\
Almost Never & Hampir Tidak Pernah Terjadi & $>6.000$ jam operasi \\
UnLikely & Kemungkinan Terjadi Ada Tetapi Kecil (jarang) & mesin \\
Possible & Kemungkinan Saja Terjadi (Kadang-kadang) & 401-1. 000 jam operasi. \\
Likely & Kemungkinan Besar Terjadi (Sering) & $11-100$ jam operasi. \\
Almost Certain & Hampir Selalu Terjadi (Sangat Sering) & $<2$ jam oprasi \\
\hline
\end{tabular}

Dan dari segi dimensi dampak atau efeknya dibagi ke dalam lima kategori, yaitu minor, moderate, severe, major, dan worse case, seperti ditunjukkan pada Tabel 2 dibawah ini :

Tabel 2. Dampak Risiko (Impact)

\begin{tabular}{ll}
\hline & Dampak (Imapact) \\
\hline Level & Dampak \\
Minor & Dampaknya Sangat Kecil \\
Moderate & Dampaknya Kecil \\
Severe & Dampaknya Cukup Besar \\
Major & Dampaknya Besar \\
Worse Case & Dampaknya Sangat Besar \\
\hline
\end{tabular}

2.2 Penentuan Prioritas Pengendalian Risiko dengan Metode FuzzyFMEA

Analisis risiko kerusakan di unit mesin bagging Scale dimulai dengan mengidentifikasi berbagai jenis kerusakan yang terjadi dari hasil identifikasi risiko yang dilakuakan sebelumnya. Kemudian dilanjutkan dengan melakukan penilaian risiko kerusakan dan menentukan prioritas perbaikannya dengan metode Fuzzy FMEA. Pada FMEA konvensional, penilaian risiko suatu kegalalan atau kerusakan diperoleh dengan mengalikan skor Severity (S), Occurance $(O)$, dan Detection (D), yang hasilnya berupa nilai Risk Prioriy Number $(R P N)$.
$\mathrm{RPN}=\mathrm{S} \times \mathrm{O} \times \mathrm{D}$

Dimana skor nilai S, O, dan D masingmasing menggunakan skala penilaian 1-10 pada FMEA konvensional. Adapun yang menjelaskan tentang rating penilaian dari ketiga faktor risiko tersebut terdapat pada Gambar 1 sampai Gambar 3:

\begin{tabular}{|c|c|c|c|}
\hline \multicolumn{4}{|c|}{ Rating Soversig pada FaIFA Peramatun } \\
\hline Renkingy & Allibat & Ëriteria Verbal & Alibat pada produlsi \\
\hline 1 & Tists' ads ablhat & 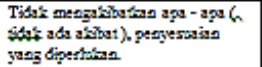 & $\begin{array}{c}\text { Prosess dolim pengentalising } \\
\text { dengan arpe. }\end{array}$ \\
\hline 2 & $\begin{array}{l}\text { Ashat sngast } \\
\text { fingas }\end{array}$ & 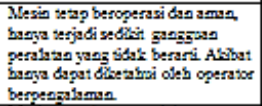 & 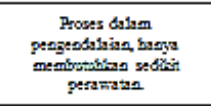 \\
\hline 3 & Albsut riggan & 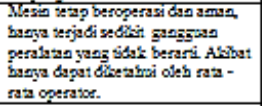 & $\begin{array}{l}\text { Proses telas berada di laser } \\
\text { pengendalian, be beraps } \\
\text { peryessian diperthen }\end{array}$ \\
\hline 4 & Asthat minose & 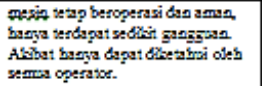 & 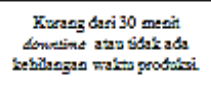 \\
\hline$s$ & Alshas moberat & 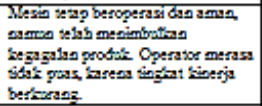 & 30 - 60 mesin Lenvitine. \\
\hline 6 & Ablost sigonition & 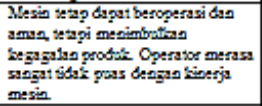 & $1-2 j a m$ \&onstine. \\
\hline 7 & Ashbst majoe & 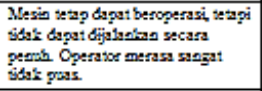 & $2-4$ jam denvitine. \\
\hline 8 & Alshat etryem & 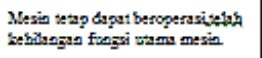 & $4-8$ jam Lenctine. \\
\hline 9 & Ashout seriss & 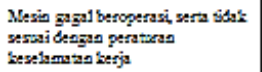 & 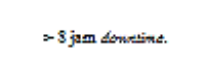 \\
\hline 10 & Asthat berbobaya & 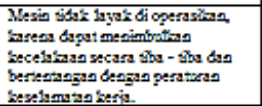 & - 8 jom dentetind. \\
\hline
\end{tabular}

Gambar 1. Rating Nilai Severity 


\begin{tabular}{|c|c|c|c|}
\hline \multicolumn{4}{|c|}{ Rating Kejadian (Ocurrence) } \\
\hline Ranking & Kejadian & Kriteria Verbal & Tingkatkejadian kenusakan \\
\hline 1 & $\begin{array}{l}\text { Hampir } \\
\text { tidal: } \\
\text { parnah }\end{array}$ & $\begin{array}{l}\text { Kens:alan bampirt tidal: } \\
\text { pamah trajadi. }\end{array}$ & $>10.000$ jem oprasi masin. \\
\hline 2 & Remots & Ken:al:an jarang trjai. & 6.001 - 10.000 jem oprasi. \\
\hline 3 & $\begin{array}{l}\text { Sangat } \\
\text { sxillitit }\end{array}$ & $\begin{array}{l}\text { Kentsalkn trigadi sangat } \\
\text { sxilist. }\end{array}$ & 3.001 - 6.000 jem opprasi. \\
\hline 4 & Sexilist & Ken:salsm trjadi sadilst. & 2.001 - 3.000 jem oprasi. \\
\hline 5 & Radigh & $\begin{array}{l}\text { Ken:alkn trijail pais } \\
\text { tinglyat endish. }\end{array}$ & $1.001-2.000$ jam opprasi. \\
\hline 6 & Medium & $\begin{array}{l}\text { Kensolism trajadi pads } \\
\text { tinglistmedium. }\end{array}$ & $401-1.000$ jem oprasi. \\
\hline 7 & $\begin{array}{l}\text { Aggl: } \\
\text { tinggi }\end{array}$ & Kens:alan trijadi ggal tinggi. & 101 -400 jam oprazi. \\
\hline 8 & Tinggi & Ken:salsm trajadi tinggi. & 11 - 100 jam oprasi. \\
\hline 9 & $\begin{array}{l}\text { Sangat } \\
\text { tinggi }\end{array}$ & $\begin{array}{l}\text { Kent:al:an trigadi sangat } \\
\text { tinggi. }\end{array}$ & $2-10$ jam operasi \\
\hline 10 & $\begin{array}{l}\text { Hampir } \\
\text { salalu }\end{array}$ & Ken:alian salalu trjadi. & $<2$ jam орғазі. \\
\hline
\end{tabular}

Gambar 2. Rating Nilai Occurence

\begin{tabular}{|c|c|c|}
\hline \multicolumn{3}{|r|}{ Rating Detection } \\
\hline Ranking & Kejadian & Kriteria Verbal \\
\hline 1 & Hampir pasti & 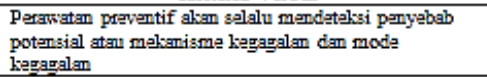 \\
\hline 2 & Sangat tinggi & $\begin{array}{l}\text { Perawatan preventif memiliki kmungkinan sangat tinggi } \\
\text { untul mandatelsi penyebab potensial atan melkanisme } \\
\text { kegagalan dan mode kagagalan. }\end{array}$ \\
\hline 3 & Tinggi & 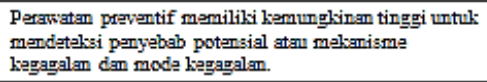 \\
\hline 4 & $\begin{array}{l}\text { Moderately } \\
\text { high }\end{array}$ & 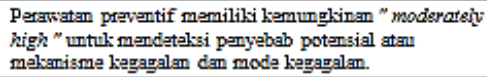 \\
\hline 5 & Maderate & $\begin{array}{l}\text { Perawatan preventif memiliki kemungkinan " modsrate " } \\
\text { untuk mendisteksi penyebab potensial atan melkanisme } \\
\text { kagagalan dan mode kagagalan. }\end{array}$ \\
\hline 6 & Rendah & $\begin{array}{l}\text { Perawatan preventif memiliki kmungkinan rendah } \\
\text { untul mampu maditelssi pryyebab potensial atan } \\
\text { melsanisme kegagalan dan mode kegagalan. }\end{array}$ \\
\hline 7 & Sangat fandah & $\begin{array}{l}\text { Perawatan preventif memiliki kamungkinan sangat } \\
\text { rendah untul mampu mendistelsi pryyebab potensial } \\
\text { atmu melkanisme kagagalan din mode kegagalan. }\end{array}$ \\
\hline 8 & Remote & 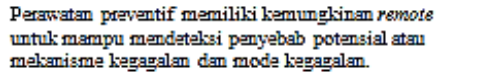 \\
\hline 9 & Verv remote & 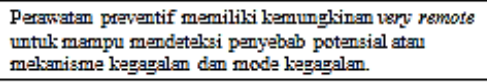 \\
\hline 10 & Tidak pasti & $\begin{array}{l}\text { Perawatan preventif alsan solalu tidal mampu menditalssi } \\
\text { pryyebab potensial atan melkanisme kegagalan dan mode } \\
\text { kagagalan }\end{array}$ \\
\hline
\end{tabular}

Gambar 3. Rating Nilai Detection

Pada metode Fuzzy FMEA, penilaian RPN tidak dilakukan seperti pada FMEA konvensional, tetapi menggunakan bilangan fuzzy untuk nilai S, O, dan D yang kemudian akan dikalikan dengan bobot kepentingan dari setiap faktor $\mathrm{S}$, O, dan $\mathrm{D}$ tersebut. Menurut Mohamed Abdelgawad dan Aminah Robinson Fayek (2010), dalam Fuzzy FMEA, proses fuzzyfikasi-nya adalah proses ketika $\mathrm{S}$, O, dan $\mathrm{D}$ dikonversi ke dalam bilangan fuzzy. Tahapan proses fuzzy FMEA:

1. Fuzzifikasi

Mendefinisikan fungsi keanggotaan input fuzzy set yang ditentukan oleh expert untuk ketiga parameter $\mathrm{S}, \mathrm{O}$, dan D sebagai input fuzzy

2. Evaluasi rule

Dengan menggunkan aturan (rule) IFTHEN yang diperoleh dari expert dan pekerja

yang digabungkan menjadi satu menjadi aturan fuzzy, aturan IF-THEN ini dapat digabungkan menjadi sebuah pemetaan dari input fuzzy ke kesimpulan fuzzy.

3. De-fuzzy-fikasi

Kesimpulan fuzzy dapat diubah menjadi sebuah nilai rill yang merepresentasikan risiko.

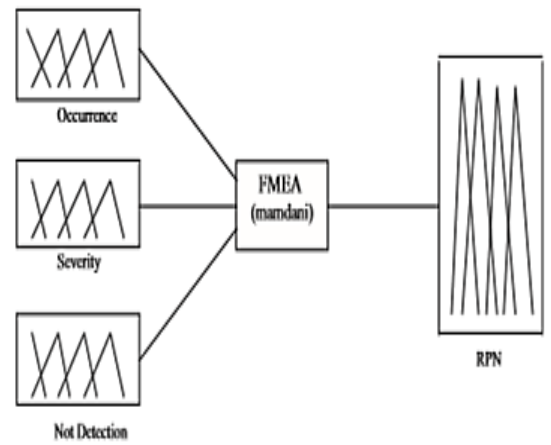

Gambar 4. Model Fuzzy FMEA

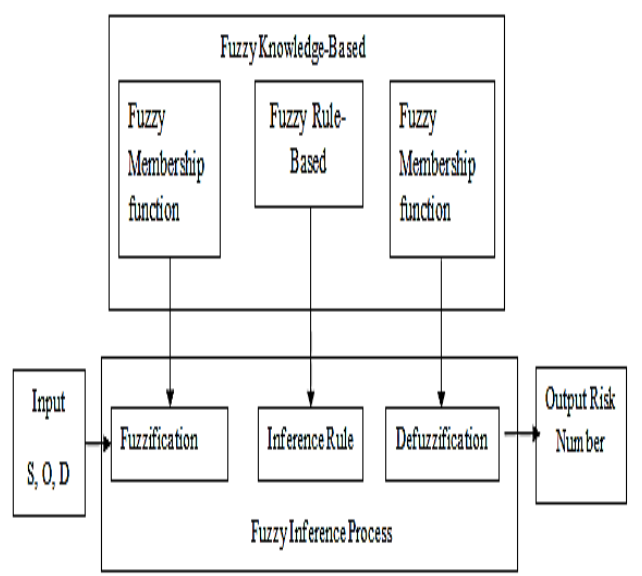

Gambar 5. Risk Evaluation steps with Fuzzy FMEA 
FMEA konvensional secara signifikan tidak memperhitungan kepentingan relatif dari faktor-faktor risiko dan memperlakukannya dalam tingkat kepentingan yang sama atau hanya melihat hasil nilai RPN nya saja. Untuk itu bobot kepentingan relatif dari faktor-faktor risiko akan dinilai menggunakan istilah linguistik. Berdasarkan alasan ini, penerapan logika fuzzy sangat tepat untuk mengakomodasi masalah yang ada pada FMEA konvensional. Dalam metode Fuzzy FMEA menggunakan metode mamdani. Metode mamdani sering dikenal dengan metode Max-Min. Metode ini diperkenalkan oleh Ebrahim Mamdani pada tahun 1975 untuk memdapatkan Output Fuzzy Tiga parameter ( keparahan, kejadian, dan deteksi ) digunakan sebagai obat untuk menjelaskan setiap mode kegagalan masukan variabel skala 1-10, yang dikelompokkan ke dalam lima tingkatan dari Almost None sampai very high. seperti pada tabel berikut:

Table 3. Fuzzy FMEA Variable Input Category

\begin{tabular}{cccc}
\hline \multicolumn{3}{c}{ Input } & Category \\
\cline { 1 - 3 } $\mathrm{S}$ & $\mathrm{O}$ & $\mathrm{D}$ & \\
\hline 1 & 1 & 1 & Almost None \\
\hline 2.3 & 2.3 & 2.3 & Low \\
$4,5,6$ & $4,5,6$ & $4,5,6$ & Medium \\
7,8 & 7,8 & 7,8 & High \\
$9,10$. & $9,10$. & $9,10$. & Very High \\
\hline
\end{tabular}

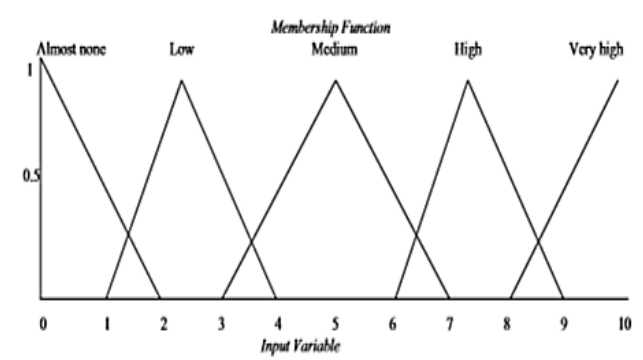

Gambar 6. Input variable membership function

Kemudian variabel output adalah nilai RPN, digunakan untuk mewakili prioritas dalam menetukan tindakan korektif dengan skala 1-100, yang dikategorikan ke dalam interval sebanyak sembilan kelas yang dijelaskan pada Tabel. 4 dan fungsi keanggotaan fuzzy variabel output pada Gambar. 5

Table 4. Fuzzy FMEA Variable Output Category

\begin{tabular}{ll}
\hline Fuzzy Output & Category \\
\hline$(10,10,20)$ & AN \\
$(10,20,30)$ & VL \\
$(20,30,40)$ & L \\
$(40,50,60)$ & L-M \\
$(50,60,70)$ & M \\
$(60,70,80)$ & H-M \\
$(70,80,90)$ & L-H \\
$(80,90,100)$ & H \\
$(90,100,100)$ & VH \\
\hline
\end{tabular}

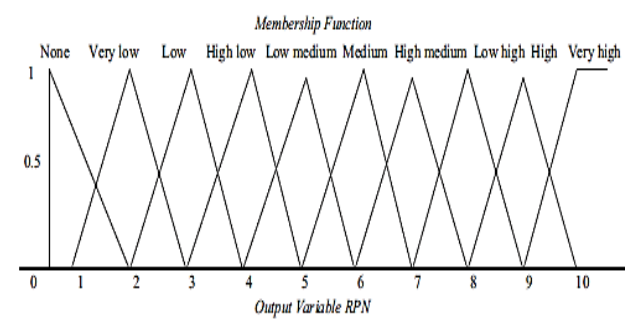

Gambar 7. Output Variable Membership Function Fuzzy FMEA

\section{HASIL DAN PEMBAHASAN}

\subsection{Identifikasi risiko}

Pada Tabel 5 menjelaskan hasil rekapitulasi penilaian risiko dari identifikasi risiko kerusakan apa saja yang terjadi pada mesin Bagging Scale.

Berdasarkan hasil identifikasi resiko dari mesin bagging scale yang dilakuakan, dapat dilihat dari hasil rekapitulasi penilaian risiko, jika dilihat dari segi dampaknya Risiko terbesar terjadi pada kasus baut bucket yang bergeser tidak sesuai posisi, unit power supplay melemah, dan selenoin kelebihan power. Dampak dari risiko tersebut sangat besar karena jika terdapat masalah pada tiga komponen mesin tersebut, mesin harus stop beroprasi. Tetapi, dari tingkat sering terjadinya masalah tersebut masuk dalam katagori (possible) kadang-kadang saja terjadi atau tidak terlalu sering. Penanganan terhadap risiko yang memilki dampak yang sangat besar (worse case) yaitu perusahan harus mengurangi risiko dengan diadakannya preventive maintenance dengan intensitas 
perawatan yang lebih agar dampak risiko yang teradi lebih terminimalisir. Sedangkan jika kita lihat dari segi kemungkinan munculnya risiko terdapat pada kasus bag coding kotor yang sangat sering terjadi (Almost Certain). Namun, dampak dari masalah tersebut masih kecil (moderate). Bag Coding yang sering kotor disebabkan menempelnya urea kebagian bag coding dikarenakan sifat urea yang hidroskopis sehingga urea mudah menempel. Akibat dari kasus tersebut yaitu kode tidak muncul pada karung dan oprator harus menulis secara manual. Apabila suatu masalah sangat sering terjadi penanganan yang dilakukan sebaiknya menghindari risiko tersebut yaitu dengan cara operator harus disiplin dalam mengupayakan bag coding harus selalu bersih agar code pada karung bisa terlihat dengan jelas dan mempercepat proses pengantongan.

Tabel 5. Rekapitulasi Penilaian Risiko

\begin{tabular}{|c|c|c|c|}
\hline No & Risiko & Impact & Likelihood \\
\hline 1 & Unit Power Supplay melemah & Worse case & Possible \\
\hline 2 & Selenoid Kelebihan Power & Worse case & Possible \\
\hline 3 & Selenoid Dribble Feed kotor & Major & Unlikely \\
\hline 4 & Gantungan Load Cell Aus & Major & Possible \\
\hline 5 & Urea tumpah ke Bucket & Major & Unlikely \\
\hline 6 & Pada bagian trigger sensor tidak bisa di matikan & Major & Possible \\
\hline 7 & Pompa Dribble kotor & Major & Possible \\
\hline 8 & Udara kurang / Air Cylinder bocor & Major & Unlikely \\
\hline 9 & Buacket berkarat / las-lasan lepas & Major & Unlikely \\
\hline 10 & Bucket Berkarat & Major & Likely \\
\hline 11 & Bergesernya baut pada Bucket dengen posisi tidah sesuai & Worse case & Possible \\
\hline 12 & Usia Seal (karet) dan kurangnya oli Pompa Dump Door & Major & Possible \\
\hline 13 & Pompa Dump Door macet & Moderate & Unlikely \\
\hline 14 & Pompa Bag Clamp tidak ada udara & Moderate & Possible \\
\hline 15 & Pompa Bag Clamp keset tidak bisa menjepit & Major & Possible \\
\hline 16 & Bag Coding Kotor & Moderate & Almost Certain \\
\hline 17 & Controll Bag Coding rusak & Moderate & Likely \\
\hline 18 & Controll Print Bag Coding rusak & Moderate & Likely \\
\hline 19 & Plan Roll korosi & Moderate & Unlikely \\
\hline 20 & Return Roll korosi & Moderate & Unlikely \\
\hline 21 & Motor Race Pully kotor & Major & Unlikely \\
\hline 22 & Oli bocor dibagian Seal & Major & Unlikely \\
\hline 23 & Benang kendor & Moderate & Unlikely \\
\hline 24 & Jarum Rusak & Moderate & Unlikely \\
\hline
\end{tabular}

3.2 Penilaian Faktor Risiko dan (severity), tingkat sering terjadinya risiko Penentuan Usulan Prioritas Per- (occurence), dan apakah risiko tersebut baikan Dengan Metode Fuzzy FMEA mudah ataupun sulit untuk dideteksi Setelah dilakuan identifikasi risiko apa (detection). Kemudian akan didapatkan nilai saja yang terjadi. Selanjutnya melakukan Risk Priority Number (RPN) dari tiap risiko penentuan prioritas perbaikan untuk mesin atau moda kegagal yang terjadi. Tabel 6 bagging scale berdasarkan penilaian faktor- dibawah ini menunjukan penilaian risiko faktor risiko dengan menggunakan metode FMEA konvensional. Faktor-faktor risiko dengan tabel FMEA. tersebut meliputi tingkat keparahan 
Tabel 6. Penilaian dan Perhitungan RPN pada FMEA konvensional

\begin{tabular}{clcccc}
\hline No & Risiko & S & O & D & RPN \\
\hline 1 & Unit Power Supplay melemah & 7 & 4 & 8 & 224 \\
2 & Selenoid Basah dan Kelebihan Power & 7 & 4 & 8 & 224 \\
3 & Selenoid Dribble Feed kotor & 7 & 3 & 8 & 168 \\
4 & Gantungan Load Cell Aus & 4 & 5 & 8 & 160 \\
5 & Urea tumpah ke Bucket & 7 & 3 & 8 & 168 \\
6 & Pada bagian trigger sensor tidak bisa di matikan & 5 & 5 & 8 & 200 \\
7 & Pompa Dribble kotor & 6 & 5 & 8 & 240 \\
8 & Udara kurang / Air Cylinder bocor & 7 & 7 & 8 & 392 \\
9 & Buacket berkarat / las-lasan lepas & 4 & 3 & 8 & 96 \\
10 & Bucket Berkarat & 5 & 3 & 8 & 120 \\
11 & Bergesernya baut pada Bucket dengen posisi tidah sesuai & 4 & 6 & 8 & 192 \\
12 & Usia Seal (karet) dan kurangnya oli Pompa Dump Door & 5 & 5 & 8 & 200 \\
13 & Pompa Dump Door macet & 5 & 4 & 8 & 160 \\
14 & Pompa Bag Clamp tidak ada udara & 4 & 5 & 8 & 160 \\
15 & Pompa Bag Clamp keset tidak bisa menjepit & 4 & 5 & 8 & 160 \\
16 & Bag Coding Kotor & 4 & 8 & 8 & 256 \\
17 & Controll Bag Coding rusak & 6 & 7 & 8 & 336 \\
18 & Controll Print Bag Coding rusak & 4 & 7 & 8 & 224 \\
19 & Plan Roll korosi & 4 & 2 & 9 & 72 \\
20 & Return Roll korosi & 4 & 2 & 9 & 72 \\
21 & Motor Race Pully kotor & 6 & 3 & 7 & 126 \\
22 & Oli bocor dibagian Seal & 5 & 3 & 8 & 120 \\
23 & Benang kendor & 4 & 3 & 7 & 84 \\
24 & Jarum rusak & 4 & 4 & 8 & 128 \\
\hline
\end{tabular}

Berdasarkan hasil perhitungan FMEA konvensional diatas didapatkan nilai RPN yang bervariasi, dengan nilai terkecil sebesar 72 dan nilai terbesarnya adalah 392 . Terdapat beberapa jenis kerusakan yang memiliki nilai RPN sama, dan nilai $S$, O, dan $D$ nya jaga sama dan nantinya perioritas yang dihasilkanpun pun juga sama. Hal itu disebabkan dari subsistem moda kegagalannya mempunyai tingakat keparahan yang sama, dan tingkat terjadinya yang sama walaupun diwaktu yang berbeda, serta menurut ahlinya semua kejadian tersebut sudah sedikit mampu untuk langsung diditeksi dari setiap kerusakan yang timbul. Tetapi ada juga yang memilki nilai RPN sama tetapi nilai $S, O$, dan $D$ nya berbeda. misalnya pada no 4,13 , dan 14 dengan nilai RPN sebesar 160. Secara matematis, tingkat risiko terhadap kegagalan proses pengantongan adalah sama. Padahal, apabila disesuaikan dengan kondisi nyata, kerusakan no 4 akan menghasilkan efek kegagalan produksi yang lebih besar dari pada kerusakan no 13 dan no 14. Sebab timbangan pada karung pupuk urea tidak akurat dan akan menimbulkan kerugian bagi perusahaan. Dari hasil perhitungan FMEA konvensional tersebut akan disempurnakan serta dibandingkan dengan perhitungan nilai RPN dengan metode Fuzzy FMEA untuk menentukan usulan prioritas perbaikan pada mesin pengantongan demi menimalkan risiko. Tabel. 7 dibawah ini menunjukan hasil perbandingan nilai RPN dengan FMEA konensional dengan nilai RPN yang sudah disempurnakan dengan metode Fuzzy. 
Tabel 7. Hasil Perhitungan Prioritas Risiko Kerusakan dengan Fuzzy FMEA

\begin{tabular}{clcccc}
\hline & \multicolumn{1}{c}{ Failure Mode } & RPN & Prioritas & RPN & Prioritas \\
No & \multicolumn{1}{c}{ Ruzy } \\
\hline 1 & Unit Power Supplay melemah & 224 & 5 & 70 & 14 \\
2 & Selenoid Basah dan Kelebihan Power & 224 & 6 & 70 & 15 \\
3 & Selenoid Dribble Feed kotor & 168 & 11 & 80 & 6 \\
4 & Gantungan Load Cell Aus & 160 & 13 & 80 & 7 \\
5 & Urea tumpah ke Bucket & 168 & 12 & 70 & 16 \\
6 & Pada bagian trigger sensor tidak bisa di matikan & 200 & 8 & 80 & 3 \\
7 & Pompa Dribble kotor & 240 & 4 & 80 & 2 \\
8 & Udara kurang / Air Cylinder bocor & 392 & 1 & 80 & 1 \\
9 & Buacket berkarat / las-lasan lepas & 96 & 21 & 70 & 20 \\
10 & Bucket Berkarat & 120 & 19 & 70 & 18 \\
11 & Bergesernya baut pada Bucket dengen posisi tidak sesuai & 192 & 10 & 80 & 5 \\
12 & Usia Seal (karet) dan kurangnya oli Pompa Dump Door & 200 & 9 & 80 & 4 \\
13 & Pompa Dump Door macet & 160 & 14 & 80 & 8 \\
14 & Pompa Bag Clamp tidak ada udara & 160 & 15 & 80 & 9 \\
15 & Pompa Bag Clamp keset tidak bisa menjepit & 160 & 16 & 80 & 10 \\
16 & Bnyaknya urea yang menempel pada Bag Coding & 256 & 3 & 60 & 23 \\
17 & Controll Bag Coding rusak & 336 & 2 & 60 & 22 \\
18 & Controll Print Bag Coding rusak & 224 & 7 & 60 & 24 \\
19 & Plan Roll korosi & 72 & 23 & 80 & 13 \\
20 & Return Roll korosi & 72 & 24 & 80 & 12 \\
21 & Motor Race Pully kotor & 126 & 18 & 70 & 17 \\
22 & Oli Merembas di Seal & 120 & 20 & 70 & 19 \\
23 & Benang kendor & 84 & 22 & 70 & 21 \\
24 & Jarum tidak sering diganti & 128 & 17 & 80 & 11 \\
\hline & & & & & \\
& & &
\end{tabular}

Berdasarkan hasil tabel prioritas diatas, Terdapat perbedaan hasil nilai RPN pada metode FMEA konvensional dengan metode Fuzzy FMEA. Untuk sekala prioritas pertama yang dijadikan usulan untuk diperhatikan untuk diperbaiki pada risiko diatas yaitu yang memeliki nilai RPN tertinggi dari metode FMEA konvensional sebesar 392 dan pada Fuzzy FMEA juga memiliki nilai RPN sebesar 80 adalah bocornya Air Cylinder/ Pompa Dribble karena kurangnya udara untuk membuka atau menutupnya pintu Dribble dan efeknya urea tidak bisa turun ke bucket atau urea terus turun dan tidak bisa stop/berhanti. Dan yang dijadikan prioritas akhir adalah yang memilki nilai RPN terendah yaitu bagian Controll Print Bag Coding dengan nilai RPN pada FMEA konvensional sebesar 224 dan pada metode Fuzzy FMEA sebesar 60. Hasil Risk priority Number dengan menggunakan metode Fuzzy FMEA lebih akurat dari metode FMEA konvensional yang penilaiannya diambil menurut expert saja. Tetapi, dengan metode Fuzzy FMEA hasil Risk Priority Number dikonversikan kedalam bentuk Fuzzy dengan berdasarkan 125 rules yang dibuat untuk menampilkan hasil nilai RPN yang lebih pasti serta dibuat katagori atau level nilai RPN dari terendah sampai tertinggi.

\section{PENUTUP}

\subsection{Kesimpulan}

Penggunaan metode FMEA

konvensional dalam proses analisis risiko, akan menghasilkan keputusan yang berbeda jika dibandingkan dengan menggunakan metode Fuzzy FMEA. Dengan menggunakan FMEA konvensional, jenis kerusakan yang menyebabkan risiko terbesar terhadap terhentinya proses pengantongan pupuk urea di PT. PUPUK SRIWIDJAJA yaitu jenis risiko pada no 8,17 , dan 16 . Sedangkan, apabila menggunakan metode Fuzzy FMEA 
yaitu jenis risiko pada no 8,7 , dan 6 . Jenis risiko no 8 berperan sebagai kerusakan yang memberikan potensi risiko kegagalan proses terbesar. Apabila dibandingkan dengan kondisi aktual dibagian unit pengantongan PT. PUPUK SRIWIDJAJA, maka metode Fuzzy FMEA lebih sesuai untuk diterapkan dalam hal assessment manajemen risiko. Hali ini disebebkan jika hanya menggunakan metode FMEA saja, tidak semua expert memiliki kemampuan yang sama dalam menangani kasus.

Nilai RPN yang didapat dari metode Fuzzy FMEA berkisar antara 60-80. Artinya nilai tersebut termasuk dalam katagori HighMedium $(60,70,80)$. Hal ini diartikan bahwa Faktor risiko dari moda kegagalan suatu mesin hampir mendekati faktor risiko yang tinggi. Oleh karena itu, prioritas diatas dijadikan acuan untuk fokus perbaikan atau perawatan yang lebih intensif pada mesin Bagging Scale agar lebih efisien, mesin tetap beroprasi semestinya, dan bisa mencapai target pengantongan tiap harinya.

\subsection{Saran}

Disarankan bagi penelitian berikutnya untuk mengkaji penggunaan Fuzzy FMEA yang diintegrasikan dengan metode Multi Criteria Decision Making seperti AHP atau metode lainnya agar hasil analisis suatu risiko dan respon terhapa risiko lebih akurat dan efektif.

\section{UCAPAN TERIMAKASIH}

Selesainya penelitian ini tidakk lepas dari dukungan dan bantuan banyak pihak. Untuk itu penulis ingin mengucapkan terimaksih sebanyak-banyaknya kepada Allah SWT, orang tua yang selalu memberikan dukungan serta doa, tementeman yang selalu menemani dikala susah dan senang, Bapak Agus selaku dosen pembimbing kerja praktek sekaligus dosesn pembimbing ademik yang ikhlas dalam membimbing peneliti, serta seluruh karyawan PT. PUPUK SRIWIDJAJA diarea pengantongan pupuk dan dermaga yang membantu terlaksana tugas khusus ini.

\section{DAFTAR PUSTAKA}

Basjir. N, et al. Pengembangan Model Penentuan Prioritas Terhadap Moda Kegagalan Komponen Dengan Metode FMEA, FUZZY, Dan TOPSIS Yang terintegrasi. 2011.

Bsuki, Ari. Manajemen risiko kerusakan di unit pengemasan PT. Semen Indonesia, Tbk. Pabrik Tuban. 2015.

Harahap, M. Rudy. Pengukuran risiko aset teknologi infirmasi berbasis PBI pada sektor perbankan di Indonesia. 2010.

Miftah F. Indra. Usulan Perencanaan Perawatan Mesin Bantu Kapal DAIHATSU 6 PSHTC - 26H Dengan Metode Reability Centered Maintenance II (RCM II). 2014.

Ming wang. Ying. Risk Evaluation Failure Mode and Effect Analysis Using Fuzzy Weighted Geometric Mean. 2007.

Rezapahlevi. M (X). Risk Analysis On Auxiliary Engine Daihatsu 6 PSHTC26H Using Fuzzy FMEA.

Saifudin, Mohammad. H. Analisis risiki operasional pada divisi bengkel PT. XYZ Branch Office Malang. 2014.

Sudarsono. k, et al. Analisis risiko operasional PT. TELKOM dengan pendekatan metode ERM. 2008. 